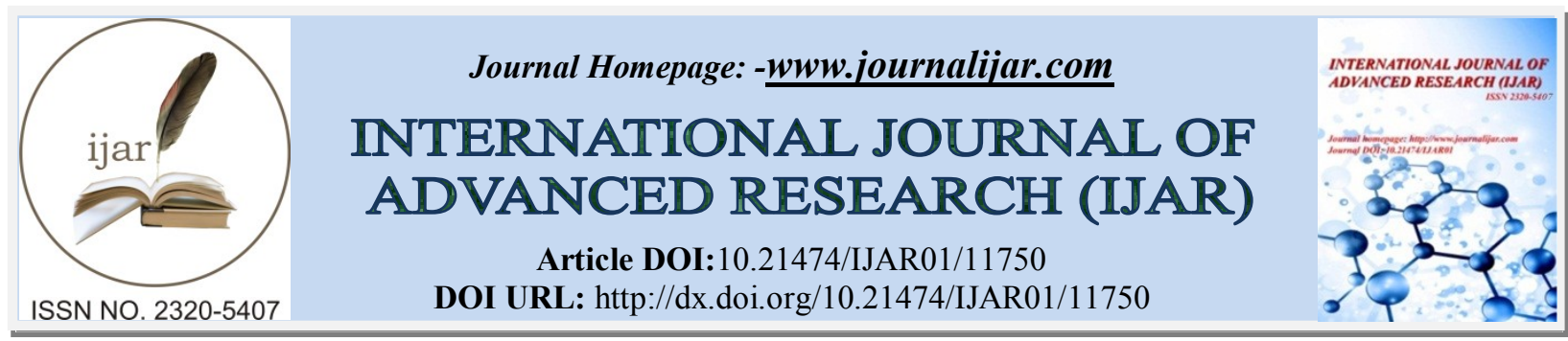

RESEARCH ARTICLE

\title{
LAISSEZ-FAIRE LEADERSHIP POSITIVELY IMPACTS ORGANISATIONAL COMMITMENT IN HEALTHCARE CENTRES IN QATAR
}

\author{
Shaher Alshamari, PhD \\ Debrecen Károly Ihrig (Doctoral School of Management and Business, University of Debrecen), Debrecen, \\ Hungary.
}

\section{Manuscript Info}

..........................

Manuscript History

Received: 20 July 2020

Final Accepted: 24 August 2020

Published: September 2020

Key words:-

Leadership Style, Laissez-

Faire,Organisational Commitment

\section{Abstract}

Leadership engenders an essential element for organisations to develop business strategies and achieve their goals. This research aims to examine the impact of laissez-faire leadership style on organisational commitment (OCOM) in health care centers in Qatar. The researcher adopted a quantitative approach, using a self-administered questionnaire to collect the primary data. The sample consisted of 218 leaders and supervisors from five healthcare centers in Qatar selected employing non-random sampling. The study indicated a significant positive relationship existed between laissez-faire leadership and OCOM. Moreover, leadership behavior significantly impacted OCOM behaviors. but in different degrees: continuance commitment and normative commitment to a higher extent, and affective commitment less so. Also, the results showed the percentage to which Laissez-Faire leadership style was practiced, in the sample, to be high.

Copy Right, IJAR, 2020,. All rights reserved.

\section{Introduction:-}

The leadership style promoting employee commitment helps institutions to realise their aims (Erasmus \& Schenk, 2004; Mahdi et al., 2014). Accordingly, leaders of healthcare systems in Qatar need to pay more attention to their leadership behavior, promoting and instilling employee commitment and loyalty to accomplish company objectives.

Changes and developments have affected healthcare institutions and leaders. In the medical profession, individuals interact and are exposed to constant scientific and technological advancements. This paper focuses on Qatar's public healthcare centres' leadership styles. Despite its small size, in the past few years, Qatar's medical sector has significantly expanded its infrastructure and the range of patient services. It hosts the highest health workforce densities in the world (Oxford Business Group, 2019) The World Bank's most recent data showed the country's per capita health spending rated among the highest in the Middle East, and the government allocated $\$ 6.23$ billion to the health sector, representing $11 \%$ of its budget (Oxford Business Group, 2019).

Although no single leadership style is considered appropriate or applicable to every manager, under all circumstances (Amgheib, 2016), the intention of this empirical study is to illuminate the effect of laissez-faire leadership on organisational commitment in public healthcare centers in Qatar.

Corresponding Author:- Shaher Alshamari

Address:- Debrecen Károly Ihrig (Doctoral School of Management and Business, University of

Debrecen), Debrecen, Hungary. 


\section{Methods:-}

The researcher used a quantitative methodology to collect data in a cross-sectional survey among medical staff, including leaders and supervisors of five healthcare centres in Qatar. Purposive sampling was used, for the researcher sent the questionnaire to employees with job position relevant to the research. Prospective participants received a hard-copy questionnaire to participate in the study, and they were informed of the investigation's objectives and ensured participation was voluntary, and responses would be kept confidential. The population equaled approximately 2,590 medical employees. The sample size was calculated based on Krejcie and Morgan's table. According to Sekaran \& Bougie (2016), Krejcie \& Morgan (1970) simplified the sample size decision by providing a table suggesting population size and sample size. Therefore, the sample size entailed 335 individuals. Table 1 illustrates the sample distribution across medical centres, highlighting the data collection.

Table 1:- Data Distribution Across the Sample.

\begin{tabular}{|l|l|l|l|l|}
\hline Centre Code & Name of Health Centre & $\begin{array}{l}\text { Questionnaires } \\
\text { Distributed }\end{array}$ & $\begin{array}{l}\text { Questionnaires } \\
\text { Collected }\end{array}$ & $\begin{array}{l}\text { Response } \\
\text { Rate }\end{array}$ \\
\hline 01 & Al-Rayyan & 67 & 65 & $97 \%$ \\
\hline 02 & Mesimeer & 80 & 80 & $100 \%$ \\
\hline 03 & Al-Muntazah & 90 & 90 & $100 \%$ \\
\hline 04 & Al Mataar & 50 & 50 & $100 \%$ \\
\hline 05 & Al Wajba & 51 & 50 & $98 \%$ \\
\hline Total & 338 & 335 & $99 . \%$ \\
\hline
\end{tabular}

Excluding disinterested respondents $(n=3), 335$ respondents (99\% response rate) remained. Arabic versions of the English scales were created using a translation-back-translation procedure (Schaffer \& Riordan, 2003). Responses, based on a a five-point Likert scale, ranged from 1 (strongly disagree) to 5 (strongly agree), unless otherwise specified.

In the final sample used for analyses, most participants were male $(55.22 \%)$, between 31 and 40 years of age $(39.40 \%)$, worked as nurses $(44.78 \%)$, and had more than five to ten years work experience $(29.85 \%)$. The health centres were distributed in three locations (north, centre, and west), with participant representation 20\%, 60\%, and $20 \%$, respectively. See Table 2 .

Table 2:- Medical Staff Demographics ( $\mathrm{n}=335)$.

\begin{tabular}{|c|c|c|c|}
\hline Item & Category & Frequency & Percent \\
\hline \multirow{2}{*}{ Gender } & Male & 185 & $55.22 \%$ \\
\hline & Female & 150 & $44.78 \%$ \\
\hline \multirow[t]{5}{*}{ Age } & Total & 335 & $100 \%$ \\
\hline & $20-30$ years & 120 & $35.82 \%$ \\
\hline & $31-40$ years & 132 & $39.40 \%$ \\
\hline & $41-50$ years & 83 & $24.78 \%$ \\
\hline & Total & 335 & $100 \%$ \\
\hline \multirow[t]{7}{*}{ Job title } & Medical doctor & 80 & $23.88 \%$ \\
\hline & Nurse & 150 & $44.78 \%$ \\
\hline & Pharmacist & 60 & $17.91 \%$ \\
\hline & Dentist & 30 & $8.96 \%$ \\
\hline & Medical heads & 10 & $2.99 \%$ \\
\hline & Health centre Manager & 5 & $1.49 \%$ \\
\hline & Total & 335 & $100 \%$ \\
\hline \multirow[t]{5}{*}{ Work Experience } & 1 to 5 years & 80 & $23.88 \%$ \\
\hline & more than 5 to 10 years & 100 & $29.85 \%$ \\
\hline & more than 10 to 15 years & 80 & $23.88 \%$ \\
\hline & more than 15 to 20 years & 75 & $22.39 \%$ \\
\hline & Total & 335 & $100 \%$ \\
\hline \multirow{2}{*}{$\begin{array}{ll}\text { Health } & \text { Centre } \\
\text { LOCOMation } & \\
\end{array}$} & North & 1 & $20 \%$ \\
\hline & Central & 3 & $60 \%$ \\
\hline
\end{tabular}




\begin{tabular}{|l|l|l|l|}
\hline West & & 1 & $20 \%$ \\
\hline Total & & 5 & $100.00 \%$ \\
\hline
\end{tabular}

Participants completed a questionnaire asking demographic questions and used a seven-item version (Hinkin \& Schriesheim, 2008a; 2008b)of the laissez-faire scale from the Multifactor Leadership Questionnaire (MLS) 5X(Avolio \& Bass, 2004). Experts have conducted previous studies in healthcare entities to establish the external validity of the MLS (Asiri et al., 2016). Each item was rated on a scale of 0 (not at all) to 4 (frequently, if not always). The ratings were summed and divided by the number of items to derive average ratings (Hinkin \& Schriesheim, 2008a, 2008b).

The Organizational Commitment Questionnaire (OCQ) consisted of 18 items, of which six contained negatively phrased questions to elicit the affective commitment (AF) of medical professionals (Mowday et al., 1979). A Likert scale rating of one indicated 'strongly disagree,' and seven referred to 'strongly agree.' The tool's reliability is well established, with reported values between 0.89 and 0.94 (Mowday et al., 1982).

\section{Factor analysis:}

\section{Sample Size (pilot sample):}

The sample size remains essential in factor analysis. Scholars have disagreed regarding sample size standards, but in this study two approaches are considered. Sapnas \& Zeller (Sapnas \& Zeller, 2002) pointed out 50 cases may be adequate for factor analysis. Additionally, the sample to variable ratio depicts other recommendations for determining the number of participants required for each variable (sample to variable ratio). This ratio is often denoted as $\mathrm{N}: \mathrm{p}$ ratios where $\mathrm{N}$ refers to the number of participants, and $\mathrm{p}$ refers to the number of variables, ranging from 3:1, 4:1, 5:1, 10:1, 15:1, or 20:1 (Hogarty et al., 2005; Tabachnick \& Fidell, 2007). Hence, the sample size was $(5 * 25=125)$.

\section{Laissez-Faire Leadership Scale:}

The factorability of the seven Laissez Fair Leadership Scale (LFL) items was examined. The researcher employed several credible factorability principles for the correlation. Firstly, four of the seven components correlated at least 0.3 with at least one other item. Secondly, the Kaiser-Meyer-Olkin measure (KMO) of sampling adequacy equaled 0.774 , above the commonly recommended value of 0.6 , and Bartlett's test of sphericity was significant $\left[\chi^{2}(6, N)=\right.$ $365.77, \mathrm{p}<0.05]$. The diagonals of the anti-image correlation matrix also exceeded 0.5 . Finally, the communalities, all above 0.3 , demonstrated each element shared some common variance with other factors. These overall elements reflected a suitable factor analysis containing four items. See Table 2.

Principal components analysis (PCA) helped to identify and compute composite scores for the items underlying the short version of the laissez-faire scale from the Multifactor Leadership Questionnaire 5X. The initial eigenvalue indicated one factor explained $61.05 \%$ of the variance. The second eigenvalue was just over one, and explained $14.61 \%$ of the variance. The solution's second factor was examined using varimax and oblimin rotations of the factor loading matrix. The one-factor solution, which explained $61.05 \%$ of the variance, was preferred because of previous theoretical support, the levelling off of eigenvalues on the scree plot after one factor, and the insufficient number of primary loadings and difficulty of interpreting the second factor and subsequent factors. Little difference existed between the three-factor varimax and oblimin solutions. Thus, both solutions were examined in subsequent analyses before deciding to use a varimax rotation for the final solution.

Three items were eliminated because they did not contribute to a simple factor structure and failed to meet a minimum criterion of having a primary factor loading of 0.4 or above, and no cross-loading of 0.3 or above. For the final stage, a PCA of the remaining four items, using varimax and oblimin rotations, was conducted, with one factor explaining $61.05 \%$ of the variance. An oblimin rotation provided the best-defined factor structure. All items in this analysis had primary loadings over 0.5 . Table 4 presents the factor loading matrix for this final solution. The factor labels Hinkin \& Schriesheim (2008a) proposed suited the extracted factors and were retained. Internal consistency for scale was examined using Cronbach's alpha. The alphas were high: 0.85 for LFL (4 items). No substantial increases in alpha for any of the scales could have been achieved by eliminating more items.

A composite score was created for one factor, based on the mean of the items, having primary loadings on the factor. Higher scores indicated greater use of the coping strategy laissez-faire leadership with a negatively skewed 
distribution depicting the coping strategy the participants reported using the most. Table 3 displays the descriptive statistics. The skewness and kurtosis were well within a tolerable range for assuming a normal distribution.

Overall, these analyses revealed that one factor, highly internally consistent, underlined the responses to the short version of the LFL items. Three of the seven items were eliminated.

Table 3:- Descriptive Statistics Organisational Commitment.

\begin{tabular}{|l|l|l|l|l|l|}
\hline & Items & $\mathrm{M}(\mathrm{SD})$ & Skewness & Kurtosis & Cronbach's $\alpha$ \\
\hline LSL & 4 & $4.28(.558)$ & -0.789 & 1.351 & 0.85 \\
\hline
\end{tabular}

However, the original factor structure Hinkin \& Schriesheim proposed (2008a) was retained. Approximately normal distribution was evident for the composite score data in the current study; therefore, the data was well suited for parametric statistical analyses.

Table 4:Factor loadings and communalities based on a principal components analysis with varimax rotation for four items from the short version of the Laissez-Faire Leadership Scale (LSL) $(\mathrm{N}=125)$

\begin{tabular}{|l|l|l|}
\hline \multirow{2}{*}{ Item } & $\begin{array}{l}\text { Compo } \\
\text { nent }\end{array}$ & $\begin{array}{l}\text { Commun } \\
\text { ality }\end{array}$ \\
& LSL & \\
\hline $\begin{array}{l}1 . \\
\text { n complex situations, leaders should let subordinates work problems out on their own in the } \\
\text { health centre }\end{array}$ & 0.752 & 0.565 \\
\hline $\begin{array}{l}2 . \\
\text { eadership requires staying out of the way of subordinates as they do their work. }\end{array}$ & 0.795 & 0.632 \\
\hline $\begin{array}{l}3 . \\
\text { s a rule, leaders should allow subordinates to appraise their work. }\end{array}$ & 0.777 & 0.604 \\
\hline $\begin{array}{l}\text { 4. } \\
\text { eaders should give subordinates complete freedom to solve problems of their own. }\end{array}$ & 0.800 & 0.640 \\
\hline
\end{tabular}

Note. Factor loadings $<0.4$ are suppressed

Factor analysis: organisational commitment:

Initially, the factorability of the 18 items was examined. Several well-recognised criteria for the factorability of a correlation were used. Firstly, 14 of the 18 items correlated at least 0.3 with at least one other factor. Secondly, the $\mathrm{KMO}$ was 0.853 , above the commonly recommended value of 0.6 , and Bartlett's test of sphericity was significant $[\chi 2(91, N)=2146.74, p<0.05]$. Finally, the commonalities were all above 0.3 (see Table 4), further confirming each item shared some common variance with other elements. Given these overall indicators, factor analysis was deemed suitable with 14 items.

PCA was employed to identify and compute composite scores for the factors underlying the OCOM. Initial eigenvalues revealed the first three factors explained $25.05 \%, 21.27 \%$, and $15.75 \%$ of the variance, respectively. The fourth, fifth, and sixth factors had eigenvalues just over one, and each explained $16.12 \%$ of the variance. Solutions for four, five, and six factors were each examined using varimax rotations of the factor loading matrix. The three-factor solution, which explained $62.08 \%$ of the variance, was preferred because of its previous theoretical support, the levelling off of eigenvalues on the scree plot after three factors, and the insufficient number of primary loadings and difficulty of interpreting the fourth factor and subsequent factors. Little difference emerged between the three-factor varimax and varimax solutions. Thus, both plots were examined in subsequent analyses before deciding to use varimax rotation for the final solution.

Four items were eliminated because they did not contribute to a simple factor structure and failed to meet a minimum criterion of having a primary factor loading of 0.4 or above and no cross-loading of 0.3 or above. The 14 factors yielded factor loadings above 0.4 on affective commitment (AF), normative commitment (NC), and continuance commitment (CC).

"I would be very happy to spend the rest of my career in this organization," "I feel as if this organization's problems are my own," "I do not feel like 'part of my family' at this organization," "I do not feel 'emotionally attached' to this organization," "This organization has a great deal of personal meaning for me," and "I do not feel a strong sense of 
belonging to this organization" yielded a primary factor loadings greater than 0.5 on $\mathrm{AF}(0.764,0.762,0.714,0.674$, 0.563 , and 0.555 , respectively).

"I would feel guilty if I left my organisation now," "Even if it were to my advantage, I do not feel it would be right to leave my organisation now," "I would not leave my organisation right now because I have a sense of obligation to the people in it," and "This organisation deserves my loyalty" yielded a primary factor loadings greater than 0.5 on $\mathrm{NC}(0.766,0.742,0.713$, and 0.696 , respectively.

"I do not feel like 'part of the family' at my organisation," "I do not feel a strong sense of belonging to my organisation," "I do not feel 'emotionally attached' to this organisation," and "I do not feel any obligation to remain with my current employer" yielded a primary factor loadings greater than 0.5 on $\mathrm{CC}(0.819,0.806,0.779$, and 0.613 , respectively).

For the final stage, a PCA of the remaining 14 items, using varimax rotation, was conducted, with three factors explaining $62.08 \%$ of the variance. A varimax rotation provided the best-defined factor structure. All items in this analysis had primary loadings over 0.5 .

Internal consistency for each of the scales was examined using Cronbach's alpha. The alphas were meritorious: 0.779 for $\mathrm{AF}$ (6 items), middling 0.826 for NC (4 items), and 0.734 for CC (4 items). Eliminating more items did not yield any substantial increases in alpha for any of the scales. Overall, these analyses indicated three distinct factors $(\mathrm{AF}, \mathrm{NC}, \mathrm{CC})$ were underlying manager responses to the $\mathrm{OCOM}$, where $\mathrm{AF}, \mathrm{NC}, \mathrm{CC}$ were meritorious internally consistent.

Composite scores were created for each of the three factors, based on the mean of the items with primary loadings on each factor. Higher scores indicated greater organizational commitment. AF was the most reported organizational commitment, with a negatively skewed distribution, while NC and CCwere used considerably less and had positively skewed distributions. Descriptive statistics are presented in Table 6. The skewness and kurtosis were well within a tolerable range for assuming a normal distribution. Although a varimax rotation was used, only small correlations between each of the composite scores existed: 0.167 between affective commitment and normative; 0.132 between $\mathrm{AF}$ and $\mathrm{CC}$; and 0.141 between $\mathrm{NC}$ and $\mathrm{CC}$.

Table 5:- Factor loadings and communalities based on a principal components analysis with varimax rotation for 14 items from the Organizational commitments Scale (OCOM) $(\mathrm{N}=125)$.

\begin{tabular}{|c|c|c|c|c|}
\hline \multirow[t]{2}{*}{ Item } & \multicolumn{3}{|c|}{ Components } & \multirow{2}{*}{$\begin{array}{l}\text { Commun } \\
\text { alities }\end{array}$} \\
\hline & $\mathbf{A C}$ & NC & $\mathrm{CC}$ & \\
\hline $\begin{array}{l}1 . \\
\text { would be very happy to spend the rest of my career in this organization. }\end{array}$ & $\begin{array}{l}0.7 \\
64\end{array}$ & & & 0.481 \\
\hline $\begin{array}{l}2 . \\
\text { really feel as if this organization's problems are my own }\end{array}$ & $\begin{array}{l}0.7 \\
62\end{array}$ & & & 0.644 \\
\hline $\begin{array}{l}3 . \\
\text { do not feel like 'part of my family' at this organization. }\end{array}$ & $\begin{array}{l}0.7 \\
14\end{array}$ & & & 0.568 \\
\hline $\begin{array}{l}4 . \\
\text { do not feel 'emotionally attached' to this organization. }\end{array}$ & $\begin{array}{ll}0.6 \\
74\end{array}$ & & & 0.627 \\
\hline $\begin{array}{l}5 . \\
\text { his organization has a great deal of personal meaning for me. }\end{array}$ & $\begin{array}{l}0.5 \\
63\end{array}$ & & & 0.732 \\
\hline $\begin{array}{l}6 . \\
\text { do not feel a strong sense of belonging to this organization. }\end{array}$ & $\begin{array}{l}0.5 \\
55\end{array}$ & & & 0.625 \\
\hline $\begin{array}{l}7 . \\
\text { would feel guilty if I left my organisation now }\end{array}$ & & $\begin{array}{l}0.7 \\
66\end{array}$ & & 0.699 \\
\hline $\begin{array}{l}8 . \\
\text { ven if it were to my advantage, I do not feel it would be right to leave my } \\
\text { organisation now }\end{array}$ & & $\begin{array}{l}0.7 \\
42\end{array}$ & & 0.669 \\
\hline $\begin{array}{l}9 . \\
\text { would not leave my organisation right now because I have a sense of obligation to } \\
\text { the people in it }\end{array}$ & & $\begin{array}{l}0.7 \\
13\end{array}$ & & 0.488 \\
\hline
\end{tabular}




\begin{tabular}{|c|c|c|c|}
\hline $\begin{array}{l}10 . \\
\text { his organisation deserves my loyalty }\end{array}$ & $\begin{array}{l}0.6 \\
96\end{array}$ & & 0.651 \\
\hline $\begin{array}{l}11 . \\
\text { do not feel like 'part of the family' at my organisation }\end{array}$ & & $\begin{array}{l}0.8 \\
19\end{array}$ & 0.663 \\
\hline $\begin{array}{l}12 . \\
\text { do not feel a strong sense of belonging to my organisation. }\end{array}$ & & $\begin{array}{ll}0.8 \\
06\end{array}$ & 0.586 \\
\hline $\begin{array}{l}13 . \\
\text { do not feel 'emotionally attached' to this organisation }\end{array}$ & & $\begin{array}{l}0.7 \\
79\end{array}$ & 0.467 \\
\hline $\begin{array}{l}14 . \\
\text { do not feel any obligation to remain with my current employer }\end{array}$ & & $\begin{array}{l}0.6 \\
13\end{array}$ & 0.460 \\
\hline
\end{tabular}

Note. Factor loadings $<0.4$ are suppressed.

Table 6:- Descriptive Statistics for Organisational Commitment ( $\mathrm{N}=125)$.

\begin{tabular}{|l|l|l|l|l|l|}
\hline & Items & M(SD) & Skewness & Kurtosis & Cronbach's $\boldsymbol{\alpha}$ \\
\hline $\mathrm{AF}$ & 6 & $4.63(0.443)$ & -0.316 & 1.005 & 0.779 \\
\hline $\mathrm{NC}$ & 4 & $4.60(0.454)$ & 0.657 & 0.233 & 0.826 \\
\hline $\mathrm{CC}$ & 4 & $3.64(.751)$ & 0.703 & 0.711 & 0.734 \\
\hline
\end{tabular}

The researcher scrutinized the questionnaires results with Statistical Package for the Social Sciences (SPSS) Version 23. The relationship between leadership styles and organisational commitment was analyzed using simple regression.

\section{Literature Review:-}

Leadership encompasses the most important variable affecting an employee's relationship with their job in institutional life. Huber (2013) defined leadership as the process of working with individuals, groups, and other resources to achieve the entity goals (Lorber et al., 2018). Erkutlu (2008) suggested managers use diverse leadership styles in various work environments.

Northouse (2007) illustrated laissez-faire as a hands-off approach to leadership, where leaders abandon their responsibilities and avoid making decisions (Avolio and Bass, 2004; William \& Jones, 2006). The leader gives full freedom to the group and exercises minimal or no authority on its members (Anbazhagan \& Kotur, 2014). According to Avolio \& Bass (2004), it represents the absence of leadership, and employees working under this leadership seek assistance and supervision from alternative sources since they are left to their own devices to execute their jobs (Dubinsky et al., 1995).

Laissez-faire leadership presents a quandary that must be approached with extreme caution. On the one hand, it permitsemployees the freedomconcerning the completion of their work, encourages personal growth innovation, and allows for fasterdecision making. On the other hand, this leadership style is not appropriate for situations where employees lack the knowledge or are not good at managing projects, setting deadlines, and solving problems. The laissez-faire leader deserts responsibility, and sometimes they answer questions but avoid feedback and make little effort to satisfy employee needs (Yukl \& Gardner, 2020). Well-known business leaders have adopted laissez-faire leadership. Steve Jobs, for example, gave instructions to his groups about what he would like to see, then left them to figure out how to fulfill his wishes (Cherry, 2020).

According to Nijhof et al. (Nijhof et al., 1998), company success does not depend only on the human factor but also depends on how the institution motivates its commitment to the enterprise. Employees with OCOM are more willing to accept change and less likely to engage in withdrawal (Iverson \& Buttigieg, 1999). According to Kouzes and Posner (Kouzes \& Posner, 1997), since no unified leadership approach exists, leaders must select the way of directing based on various situations and circumstances. They need to motivate employees to participate in making decisions and solving problems to increase team and entire institutional efficiency (Lorber et al., 2018).

Yousef ( 2017)defined organisational commitment as the individual's psychological attachment to an organisation. It portrays a state of being and remaining a member of a company. Moreover, it involves feeling like a member of a family (Ibrahim, 2015).Although no universally accepted definition of OCOM exists, a common theme has emerged as a binding of the individual to an enterprise (Samad, 2005). Organisational commitment entails three forms: 
affective commitment, employee emotional attachment, and organisational involvement, and $\mathrm{CC}$, such that the employee wants to remain employed by a business, weighing the costs of leaving the organization against NC, where employees feel obligated to stay with the firm (Allen, N. Meyer, 1990; Meyer et al., 1993).

Mavens have purported laissez-faire leadership harms employee performance and organisational commitment. Amgheib ( 2016) revealed laissez-faire leaders do not seem to influence their follower work outcomes, Chaudhry \& Javed (2012)professed transformational leadership had a positive, strong and significant association with organisational commitment. The laissez-faire style does not boost the motivation of workers compared to other leadership techniques. A study conducted by Alhamadi( 2019)revealed school leaders in Abu Dhabi used both transformational and transactional leadership and rarely employed the laissez-faire approach Bass \& Stogdill (1990) and Dubinsky et al. (1995)reported a negative effect of laissez-faire leadership on salesperson job satisfaction and organisational commitment. Ming et al. (2018)revealed registered nurse leaders exhibited both transformational and transactional leadership behaviors and, to a lesser extent, laissez-faire. Scholars have not explored the impact of laissez-faire leadershipon organisational commitment in the healthcare sector in Qatar. Thus, this study aims to fill this gap with an empirical investigation into the implications of laissez-faire leadership on organisational commitment.

As defined in this approach, the leaders normally do not interfere in the decision making process. A supervisor allowing employees to make work choices makes them feel free to direct their work, and they feel responsible for their choices. Hence, the researcher formulated these hypotheses:

H1. Laissez-faire leadershippositively affects affective commitment.

H2. Laissez-faire leadershippositively affects normativecommitment.

H3. Laissez-faire leadershippositively affects continuance commitment.

Findings and analysis:

In this section, correlation and simple linear regression were performed to answer the research questions and hypotheses.

\section{Simple linear regression:}

After conducting the factor analysis and determining the components, simple regression analysis was performed to uncover the effect of laissez-faire leadership on these elements and examine the first, second and third hypotheses.

\section{Simple regression assumptions:}

To examine the hypotheses, the researcher applied simple regression. However, prior conditions and requirements must be met to ensure the test integrity and correctness:

\section{Assumption 1:}

A linear relationship exists between the independent variables and the dependent variables. Scatterplots showed this assumption was met. See Appendix 1.

\section{Assumption 2:}

The values of the residuals remained independent. The Durbin-Watson tested the residuals from linear regression, or multiple regression were independent. Test statistic values in the range of 1.5 to 2.5 are relatively normal, and residuals remained independent. Values outside of this range could be a cause for concern. The Durbin-Watson results are included in the simple regression tables.

\section{Assumption 3:}

The variance of the residuals remained constant. The plot of standardized residuals versus standardized predicted values indicated no apparent signs of funneling, suggesting homoscedasticity (see Appendix 1).

\section{Assumption 4:}

The values of the residuals were normally distributed. The histogram and p-p plot for the model supported that the assumption was met (see Appendix 1). After checking the assumptions of linear regression, all assumptions were satisfied. 


\section{Laissez-faire leadershipand organisational commitment:}

The researcher conducted simple linear regression using SPSS V23 to test the hypotheses related to laissez-faire leadershipand organisational commitment. Since the variables were measured on three organisational commitment dimensions, the relationship between organisational commitment and laissez-faire leadership was divided into three sections

\section{Laissez-faire leadership and affective commitment:}

Simple linear regression was carried out to inspect the relationship between laissez-faire leadership and AF. The scatterplot showed a moderate positive linear relationship between the variables, as confirmed with a Pearson's correlation coefficient of 0.20 . Simple linear regression revealed a significant relationship between laissez-faire leadership and $\operatorname{AF}\left[F(1,333)=11.652, p<0.001, \mathrm{R}^{2}=0.040\right]$. The slope coefficient for laissez-faire leadership was 0.266 ( $\beta 1=0.266, p<0.001)$, so the AF increased by 0.266 unit for each extra one unit of laissez-faire leadership. The $\mathrm{R}^{2}$ value was 0.040 , so $0.04 \%$ of the variation in Affective Commitment can be explained by the model containing only laissez-faire leadership. The final predictive model was:

(1) $\mathrm{AF}$ level $=3.431+\left(0.266^{*}\right.$ laissez-faire leadership $)$

Laissez-faire leadership and normative commitment:

A simple linear regression was carried out to test if laissez-faire leadership style predicted NC. The results of the regression indicated the model explained $17.8 \%$ of the variance, and the model was significant, $F(1,333)=72.07$, $\mathrm{p}<0.001$. Laissez-faire leadership significantly predicted $\mathrm{NC}(\beta 1=0.47, \mathrm{p}<0.001)$. The final predictive model entailed:

(2) $\mathrm{NC}^{\prime}=1.885+(0.47 *$ laissez-faire leadership $)$

\section{Laissez-faire leadership and continuance commitment:}

A simple linear regression was carried out to investigate the relationship between laissez-faire leadership and CC. The scatterplot showed a moderate positive linear relationship existed between the variables, confirmed with a Pearson's correlation coefficient of 0.28 . Simple linear regression showed a significant relationship between laissezfaire leadership and CC $\left[\mathrm{F}(1,333)=28.423, \mathrm{p}<0.001, \mathrm{R}^{2}=0.079\right]$. The slope coefficient for laissez-faire leadership was $0.489\left(\beta_{1}=0.489, \mathrm{p}<0.001\right)$, so the $\mathrm{CC}$ increased 0.489 units for each extra one unit of laissez-faire leadership. The $\mathrm{R}^{2}$ value was 0.076 , so $0.1 \%$ of the variation in CC can be explained by the model containing only laissez-faire leadership. The final predictive model was:

(3) $\mathrm{CC}^{\prime}=2.464+\left(0.489^{*}\right.$ laissez-faire leadership $)$

\section{Conclusion:-}

Laissez-faire leadership augmented organizational commitment as measured in terms of affective, normative, and continuance commitment. 


\section{Appendix 1:}

Affactive commitment charts:

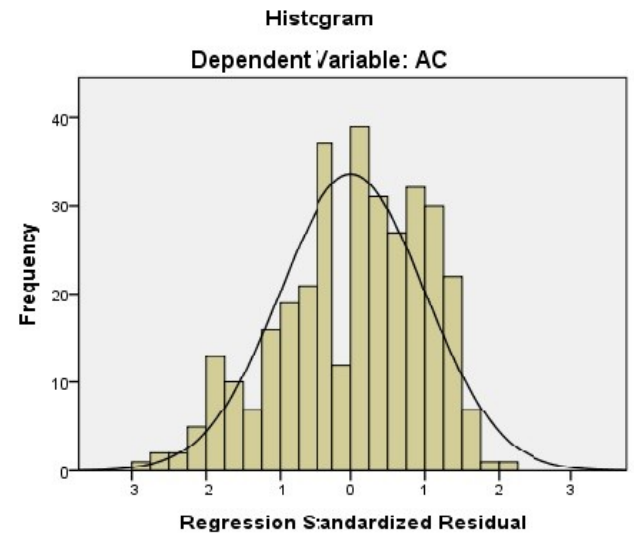

Normal P-P Plot of Regression Standardized Residual

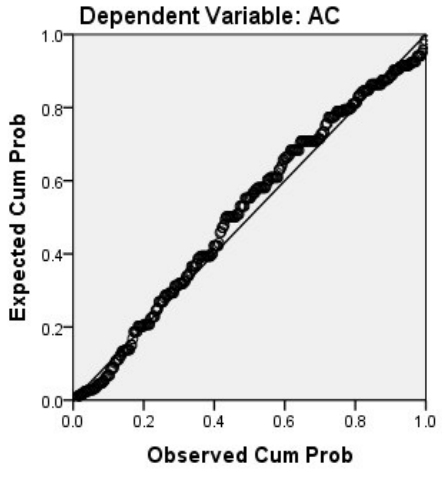

Scatterplot

Dependent Variable: AC

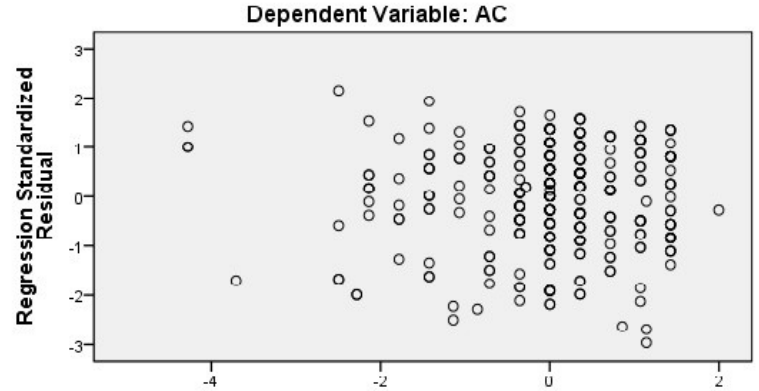

Normative Commitment charts:

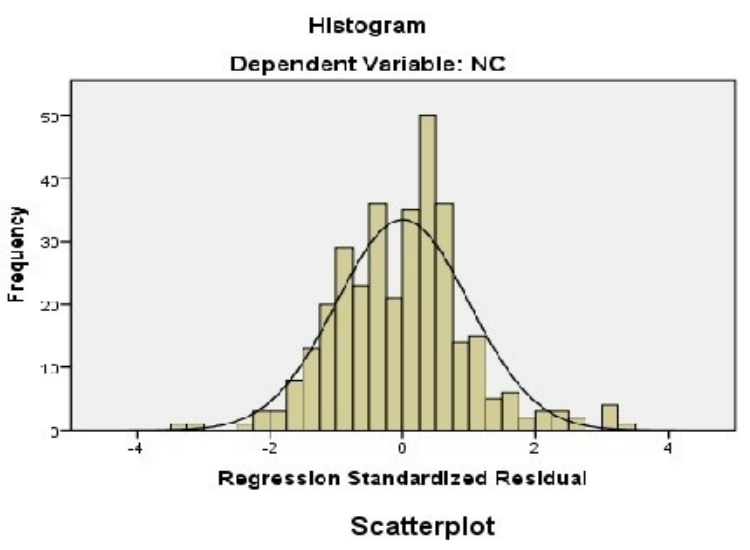

Dependent Variable: NC

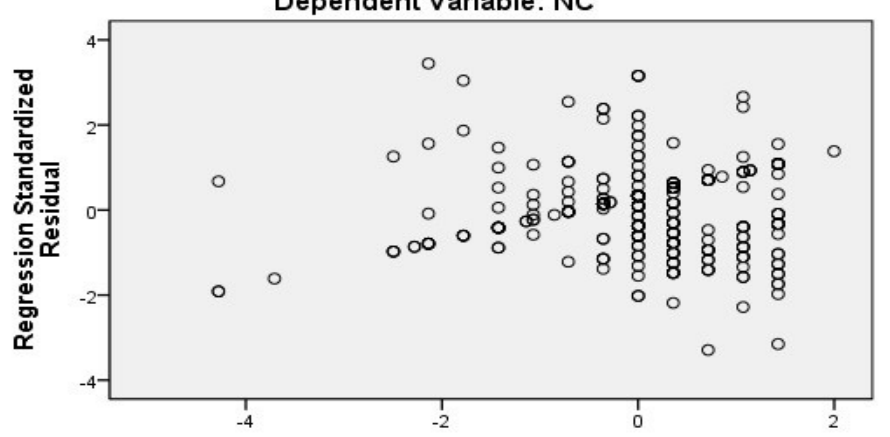

Normal P.P Plot of Regression Standardized Residual

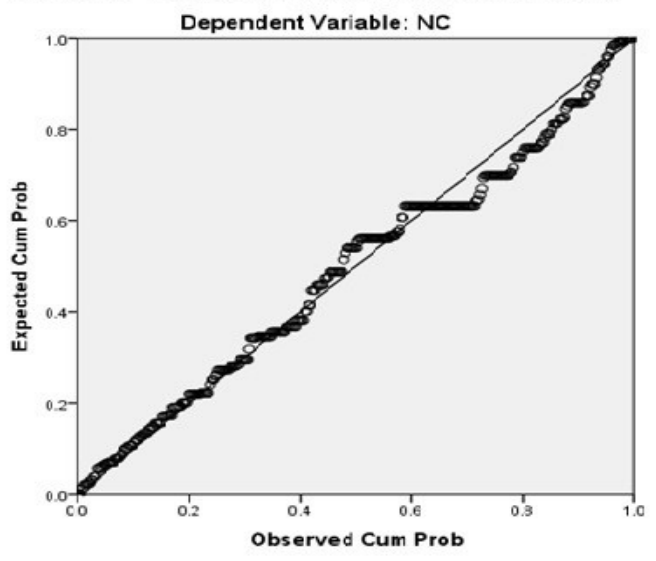




\section{Contenious commitment charts:}

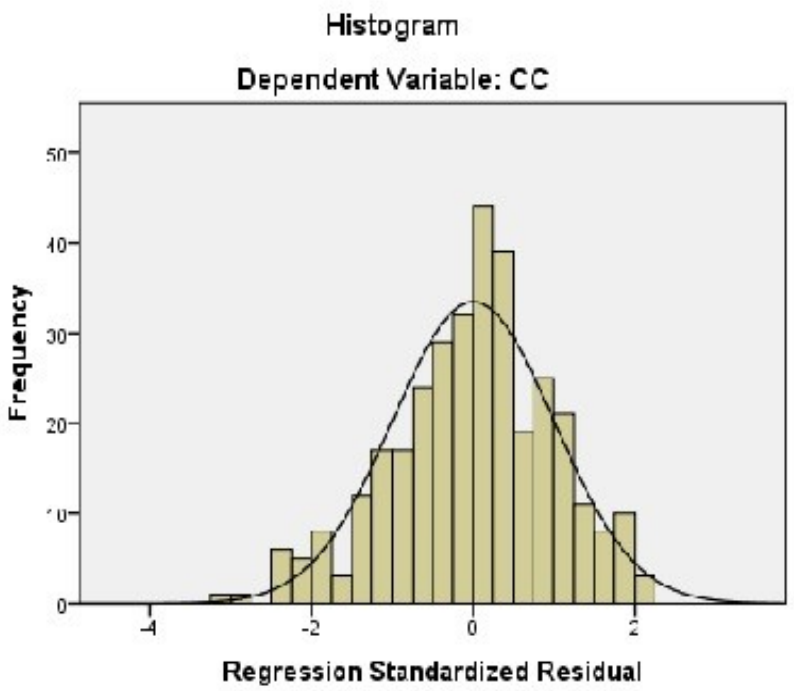

\section{Normal P.P Plot of Regression Standardized Residual}
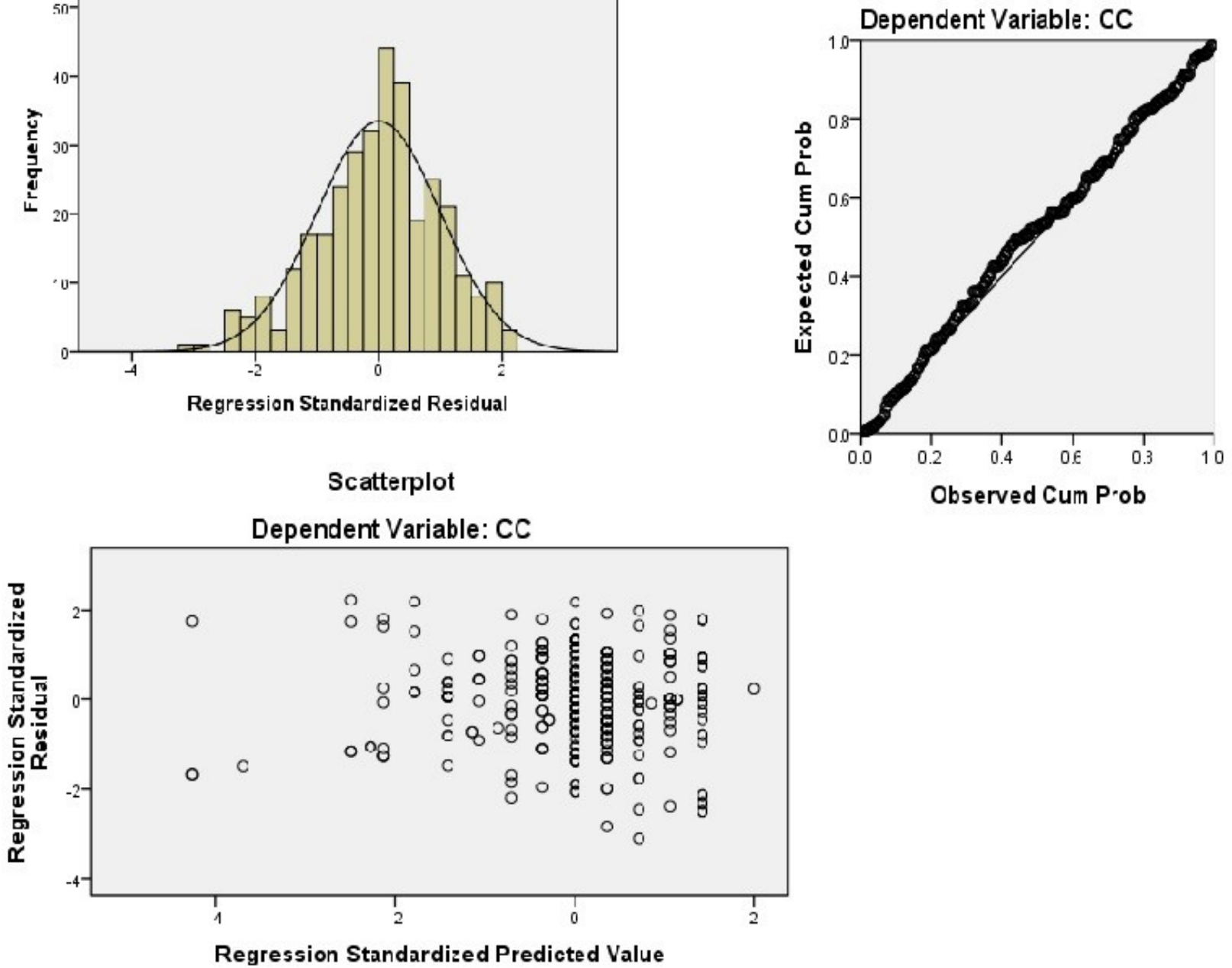

\section{References:-}

1. Alhammadi, M. A. M. A. (2019). Gender effects on leadership styles in public schools in Abu Dhabi, UAE. University of Glasgow.

2. Allen, N. Meyer, J. (1990). The measurement and antecedents of affective, continuance and normative commitment to the organization. Journal of Occupational Psychology. https://doi.org/10.1111/j.20448325.1990.tb00506.x

3. Amgheib, A. I. A. (2016). How leadership styles and follower characteristics predict follower work outcomes in Libyan organisations. https://ethos.bl.uk/OrderDetails.do?uin=uk.bl.ethos.700831

4. Anbazhagan, S., \& Kotur, B. R. (2014). Worker Productivity, Leadership Style Relationship. IOSR Journal of Business and Management, 16(8), 62-70. https://doi.org/10.9790/487x-16846270

5. Asiri, S. A., Rohrer, W. W., Al-Surimi, K., Da'ar, O. O., \& Ahmed, A. (2016). The association of leadership styles and empowerment with nurses' organizational commitment in an acute health care setting: A crosssectional study. BMC Nursing, 15(1), 38. https://doi.org/10.1186/s12912-016-0161-7

6. Avolio, B., Bass, B. (2004). Multifactor leadership questionnaire MLQ; manual and sampler set. Mind Garden. https://www.mindgarden.com/185-multifactor-leadership-questionnaire-authentic-leadership-questionnaire

7. Bass, B. and Stogdill, R. (1990). Handbook of leadership: Theory, Research \& Managerial Applications (3rd editio). NY Free Press; Collier Macmillan.

8. Chaudhry, A. Javed, H. (2012). Impact of Transactional and Laissez Faire Leadership Style on Motivation. 
International Journal of Business and Social Science, 3(7), 258-264.

9. Cherry, K. (2020). Leadership Styles and Frameworks. Very Well Mind, 1-14. https://www.verywellmind.com/leadership-styles-2795312

10. Dubinsky, A. J., Yammarino, F. J., Jolson, M. A., \& Al., E. (1995). Transformational leadership: An initial investigation in sales management. Journal of Personal Selling and Sales Management, 15(2), 17-31. https://doi.org/10.1080/08853134.1995.10754018

11. Erasmus, B., \& Schenk, H. (2004). South African human resource management: theory and practice. https://www.worldcat.org/title/south-african-human-resource-management-theory-andpractice/oclc/1127265801?referer=di\&ht=edition

12. Erkutlu, H. (2008). The impact of transformational leadership on organizational and leadership effectiveness: The Turkish case. Journal of Management Development, 27(7), 708-726. https://doi.org/10.1108/02621710810883616

13. Goh, A. M. J., Ang, S. Y., \& Della, P. R. (2018). Leadership style of nurse managers as perceived by registered nurses: A cross-sectional survey. Proceedings of Singapore Healthcare, 27(3), 205-210. https://doi.org/10.1177/2010105817751742

14. Hinkin, T. R., \& Schriesheim, C. A. (2008a). A theoretical and empirical examination of the transactional and non-leadership dimensions of the Multifactor Leadership Questionnaire (MLQ). Leadership Quarterly, 19(5), 501-513. https://doi.org/10.1016/j.leaqua.2008.07.001

15. Hinkin, T. R., \& Schriesheim, C. A. (2008b). An Examination of "Nonleadership": From Laissez-Faire Leadership to Leader Reward Omission and Punishment Omission. Journal of Applied Psychology, 93(6), 1234-1248. https://doi.org/10.1037/a0012875

16. Hogarty, K. Y., Hines, C. V., Kromrey, J. D., Ferron, J. M., \& Mumford, K. R. (2005). The Quality of Factor Solutions in Exploratory Factor Analysis: The Influence of Sample Size, Communality, and Overdetermination. Educational and Psychological Measurement, 65(2), 202-226. https://doi.org/10.1177/0013164404267287

17. Huber, D. L. (2013). Leadership and Nursing Care Management - 5th Edition. Saunders. https://www.elsevier.com/books/leadership-and-nursing-care-management/huber/978-1-4557-4071-0

18. Ibrahim, M. Y. (2015). MODEL OF COLLECTIVE EFFICACY, ORGANIZATIONAL COMMITMENT AND JOB PERFORMANCE AMONG VILLAGE LEADERS. E-Proceeding of the International Conference on Social Science Research, ICSSR 2015, 79-85.

19. Iverson, R. D., \& Buttigieg, D. M. (1999). Affective, normative and continuance commitment: Can the "right kind" of commitment be managed? Journal of Management Studies, 36(3), 307-333. https://doi.org/10.1111/1467-6486.00138

20. Kouzes, J. M., \& Posner, B. Z. (1997). Envisioning your future: Imaging ideal scenarios: James M. Kouzes and Barry Z. Posner, The Futurist (May-June 1996), pp. 14-19. In Journal of Product Innovation Management (pp. 57-58). https://doi.org/10.1016/S0737-6782(97)81442-7

21. Krejcie, R. V., \& Morgan, D. W. (1970). Determining Sample Size for Research Activities. Educational and Psychological Measurement, 30(3), 607-610. https://doi.org/10.1177/001316447003000308

22. Lorber, M., Treven, S., \& Mumel, D. (2018). Leaders' behavior in association with job satisfaction and organizational commitment. In Nursing Education, Administration, and Informatics: Breakthroughs in Research and Practice (pp. 308-330). IGI Global. https://doi.org/10.4018/978-1-5225-5490-5.ch017

23. Mahdi, O. R., Mohd, E. S. B. G., \& Almsafir, M. K. (2014). Empirical Study on the Impact of Leadership Behavior on Organizational Commitment in Plantation Companies in Malaysia. Procedia - Social and Behavioral Sciences, 109, 1076-1087. https://doi.org/10.1016/j.sbspro.2013.12.591

24. Meyer, J., Allen, N., \& Smith, C. A. (1993). Commitment to organizations and occupations: Extension and test of a three-component conceptualization. Journal of Applied Psychology, 78(4), 538-551. https://doi.org/10.1037/0021-9010.78.4.538

25. Mowday, R. T., Porter, L. M., Steers, R. M. (1982). Employee-Organization Linkages - 1st Edition (pp. 1-17). https://doi.org/https://doi.org/10.1016/B978-0-12-509370-5.50005-8

26. Mowday, R. T., Steers, R. M., \& Porter, L. W. (1979). The measurement of organizational commitment. Journal of Vocational Behavior, 14(2), 224-247. https://doi.org/10.1016/0001-8791(79)90072-1

27. Nijhof, W. J., de Jong, M. J., \& Beukhof, G. (1998). Employee commitment in changing organizations: An exploration. Journal of European Industrial Training, 22(6), 243-248. https://doi.org/10.1108/03090599810224701

28. Northouse, P. G. (2007). Leadership theory and practice, 4th ed. - PsycNET. https://psycnet.apa.org/record/2006-21567-000

29. Oxford Business Group. (2019). Demand for health services rises in Qatar| Qatar 2020 | Oxford Business 
Group. Oxford Business Group. https://oxfordbusinessgroup.com/overview/keeping-pace-private-sector-setplay-more-important-role-demand-medical-services-continues-rise

30. Samad, S. (2005). Unraveling the organizational commitment and job performance relationship: exploring the moderating effect of job satisfaction - Catholic Theological Union (CTU) - Chicago, IL. The Business Review, Cambridge, $\quad 4(2), \quad 79-84 . \quad$ https://i-sharectu.primo.exlibrisgroup.com/discovery/openurl?institution=01CARLI_CTU\&vid=01CARLI_CTU:CARLI_CT U\&volume $=4 \&$ date $=2005 \&$ aulast $=$ Samad $\&$ issue $=2 \&$ issn $=0007-7011 \&$ spage $=79 \&$ auinit $=S \&$ title $=$ The Business review.\&atitle=Unraveling the organizational commit

31. Sapnas, K. G., \& Zeller, R. A. (2002). Minimizing sample size when using exploratory factor analysis for measurement. Journal of Nursing Measurement, 10(2), 135-154. https://doi.org/10.1891/jnum.10.2.135.52552

32. Schaffer, B. S., \& Riordan, C. M. (2003). A Review of Cross-Cultural Methodologies for Organizational Research: A Best- Practices Approach. Organizational Research Methods, 6(2), 169-215. https://doi.org/10.1177/1094428103251542

33. Sekaran, U., \& Bougie, R. (2016). Research Methods For Business: A Skill Building Approach, 7th Edition | Wiley. https://www.wiley.com/eng1/Research+Methods+For+Business:+A+Skill+Building+Approach,+7th+Edition-p-9781119266846

34. Tabachnick, B. G., \& Fidell, L. S. (2007). Using multivariate statistics. https://doi.org/10.1037/022267

35. William, D., \& Jones, W. (2006). Leadership in Colleges of Agricultural and Life Sciences: An Examination of Leadership Skills, Leadership Styles, and Problem-Solving Styles of Academic Program Leaders. https://ufdc.ufl.edu/UFE0013806/00001

36. Yousef, D. A. (2017). Organizational Commitment, Job Satisfaction and Attitudes toward Organizational Change: A Study in the Local Government. International Journal of Public Administration, 40(1), 77-88. https://doi.org/10.1080/01900692.2015.1072217

37. Yukl, G., \& Gardner, W. L. (2020). Leadership in Organizations. https://lccn.loc.gov/2018041734. 